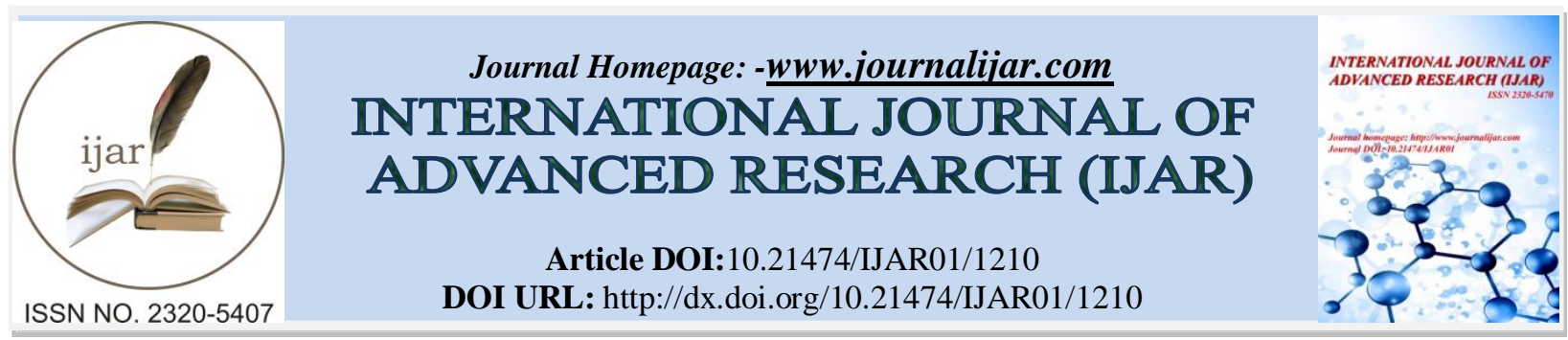

RESEARCH ARTICLE

\title{
BIOSORPTION OF CHROMIUM (VI) FROM AQUEOUS SOLUTION USING HUSK OF ANACARDIUM OCCIDENTALE L.
}

Ranganath Reddy Rachamallu.

Genomix Carl LTD, Pulivendula, A.P- India.

\section{Manuscript Info}

Manuscript History

Received: 16 June 2016

Final Accepted: 22 July 2016

Published: August 2016

Key words:-

Anacardiumoccidentale, Adsorption, Chromium, Fourier transform infrared spectroscopy (FTIR).

\begin{abstract}
Chromium (Cr) (VI) is an acutely toxic and carcinogenic metal ion. It is mobile in environment and is widely used in electroplating, stainless steel production, leather tanning, paint and textile manufacturing. Due to its known harmful effects, a focus on methods to remove this harmful metal ion is very important. In our study, we examined the potential ability of pre-treated testa (husk) of Anacardiumoccidentale (Cashew) in removal of $\mathrm{Cr}$ (VI) from aqueous solutions when usedas an adsorbent. We looked at effects of temperature, $\mathrm{pH}$, initial concentration of adsorbate, and adsorbent dosage on effective removal of Cr (VI). Data obtained was analyzed using Freundlich and Langmuir adsorption isotherms at different temperatures and related parameters for each adsorption isotherm were determined. The Langmuir adsorption potential was found to be $56.9 \mathrm{mg} / \mathrm{g}$ and the Freundlich constants $K_{f}$ and $n$ were $1.002\left[\mathrm{mg} / \mathrm{g}(1 / \mathrm{mg})^{\mathrm{n}}\right]$ and 3.4. The study also included results on the kinetic dimensions of adsorption of the $\mathrm{Cr}$ (VI) on derived adsorbent. Fourier transform infrared spectroscopy (FTIR) studies confirmed that carboxyl and hydroxyl groups were the main groups involved in the metal uptake.
\end{abstract}

Abbreviations:-Cr- Chromium; FTIR - Fourier transform infrared spectroscopy; ppm - parts per million.

Copy Right, IJAR, 2016, All rights reserved.

\section{Introduction:-}

Many researchers looked at methods for metal removal from waste water because of ecological effects of toxic metals (Volesky B, 1990; Kratochvil D and Volesky B, 1998). Water pollution due to ejection of toxic heavy metals containing effluents from industries such as textile, paint, leather tanning remain as a major environmental concern worldwide.

Chromium, in its hexavalent form, has been reported to be hazardous with group " $\mathrm{A}$ " carcinogenic property. It has been shown to play a role in modification of DNA transcription process resulting in chromosomic aberrations. Subsequently, chronic exposure to hexavalent chromium can inflict many health problems, including allergic contact dermatitis and other immunomodulatory diseases (International Agency for Research on Cancer (IARC), 1982). Effluents from above mentioned industries contain concentrations upto 100ppm of $\mathrm{Cr}$ (VI) indicating the significant need for methods for its efficient removal. 
A number of physiochemical techniques are available for chromium removal such as chemical precipitation, ion exchange, electrochemical precipitation, ultrafiltration, solvent extraction, reverse osmosis, etc (Aksu Z et al., 1996; Juang RS and Shiau RC, 2000). All these techniques are economically expensive and have major disadvantages like incomplete metal removal, high reagent and energy requirements, and generation of toxic sludge or other waste products that require disposal.

In such circumstances, an efficient and environment friendly adsorption technique is of utmost importancewith its easy operation, low cost, versatility, and ability to allow kinetics and equilibrium measurements without any highly sophisticated instruments (Volesky B and Holan ZR, 1995). Such heavy metal removal using biological materials is called biosorption. Consequently, various potential adsorbents have been researched for their ability to remove specific heavy metals from wastewater (Selvaraj K et al., 1997; Orhan Y and Büyükgüngor H, 1993; Hamadi NK, 2001;Selvaraj K et al., 2003). Much work has been carried out using seaweeds, molds, yeast, bacteria, shells, agricultural waste products like peat, coffee, coconut husk, crushed coconut shell, waste tea, defatted rice bran, rich hulls, soybean hulls, cotton seed hulls, etc (Dakiky M et al., 2002; Marshall WE and Champagne ET, 1995; Ahalya $\mathrm{N}$ et al., 2005; Ahalya $\mathrm{N}$ et al., 2010; Srinivasan K et al., 1988). These adsorbents having distinct advantage over activated carbon because of their low and easy availability. Based on our literaturereview,the adsorptive properties of testa (husk) of AnacardiumoccidentaleL., which is easily available, has not been looked at so far.

Testa (husk) of AnacardiumoccidentaleL. is an agricultural waste byproduct that is available in plenty in certain areas of India and can be potentially used for the removal of chromium (VI) ions from aqueous solution. The objective of our study was to test the feasibility of using testa (husk) of AnacardiumoccidentaleL. as a biosorbent and examine the effects of temperature, $\mathrm{pH}$, initial concentration of adsorbate, and adsorbent dosage on effective removal of $\mathrm{Cr}(\mathrm{VI})$.

\section{Materials and Methods:- Preparation of biosorbent:-}

Husk from AnacardiumoccidentaleL.(cashew) was procured from a cashew processing unit. Brownish color husk with high moisture content was washed thoroughly with tap water to remove large adhered particles and then rinsed with double distilled water. Subsequently, husk was boiled to remove color and impurities and dried at $80^{\circ} \mathrm{C}$ for 5 hours. The dried material was then ground in a well cleaned porcelain mortar. Finally, it was sieved to get a fine powder $(0.15 \mathrm{~mm})$ and stored in desiccators for subsequent use.

\section{Reagents and equipments:-}

A 1000 ppm stock solution of $\mathrm{Cr}$ (VI) is prepared by dissolving 2.8287 of analytical grade (99.9\%) potassium dichromate $\left(\mathrm{K}_{2} \mathrm{Cr}_{2} \mathrm{O}_{7}\right)$ in ultra-pure double distilled water. The complexing reagent, $0.5 \%$ diphenyl carbazide, was prepared in acetone and stored in a brown bottle for use during the study. Concentration of diphenyl carbazide complex with chromium solutions were monitored on UV-Vis Spectrophotometer with $10 \mathrm{~mm}$ matched quartz cuvettes, Model Lambda 25 (M/s Perkin Elmer Ltd, USA) over a wavelength of $540 \mathrm{~nm}$. The $\mathrm{pH}$ was adjusted using Systronics calibrated pH meter. Remi Manufacturers mechanical shaker was used for adsorption and kinetic studies.

\section{Experiments:- \\ Adsorption studies:-}

The preliminary part investigations were carried out in batches using $100 \mathrm{ml}$ borosil conical flasks at different conditions of $\mathrm{pH}$, concentration, time, amount of adsorbent, temperature, etc., to check the effects on adsorption process. After multiple meticulous trials, concentration ranges of 40-200 ppm and adsorbent amount of $1.5 \mathrm{~g} / \mathrm{L}$ were chosen. The effect of adsorbent amount was studied using varied amounts in the range of $0.5-4 \mathrm{~g} / \mathrm{L}$ with initial concentration of $\mathrm{Cr}(\mathrm{VI})$ of $100 \mathrm{ppm}$. The mixture was sporadically shaken and then kept for certain period for saturation. Subsequently supernatant liquid was filtered through Whatmann Filter Paper No.42 and the amount of metal ion adsorbed was determined spectrophotometrically at $540 \mathrm{~nm}$. All experiments were performed in triplicates.

\section{Kinetic studies:-}

Kinetic studies were carried out to measure the rates of reaction under various experimental conditions. These objective of these studies was to determine influence of concentration and temperature on rates of reaction and also to determine time requirement for the attainment of equilibrium during the adsorption process. For different initial concentrations of chromium solution ranging 40-100 mg/L with definite $\mathrm{pH}$, known amount of adsorbent was taken 
at different temperature with periodic shaking. The solutions were then filtered at different time intervals using Whatmann Filter Paper No.42 and evaluated spectrophotometrically for the amount of toxic metal.

\section{Characterization of adsorbent:-}

FTIR analyses were performed on $\mathrm{KBr}$ discs with $1 \%$ finely ground sample. They were analysed in a Perkin Elmer, Model Spectrum BXI FTIR spectrophotometer. Spectral data were processed using Spectrum 6.2 version software. The infrared spectra were recorded in the range of wave number $650-4000 \mathrm{~cm}^{-1}$ at a resolution of $4 \mathrm{~cm}^{-1}$. The cashew husk with and without adsorbed metal, were analyzed. The surface structure and metal adsorption on biosorbent was examined using Scanning Electron Microscope (SEM) combined with Energy Dispersive X-ray spectroscopy. The samples were covered with a thin layer of gold and electron acceleration voltage of $20 \mathrm{KV}$ was applied. The percentage of elements was evaluated using Energy Dispersive X-ray spectroscopic study which revealed the percentage of chromium in the biomass after biosorption.

\section{Results and Discussion:- Sorption equilibria studies:-}

In order to evaluate the chromium (VI) adsorption capacity, studies were performed with a constant adsorbent dose $(1 \mathrm{~g} / \mathrm{L})$ with different initial adsorbate concentration $(40-200 \mathrm{mg} / \mathrm{L})$ solutions and applicability of the data to the Langmuir adsorption isotherm was tested. Tests were run for sufficient time to get equilibrium at an initial pH 2. These results were adjusted to the Langmuir model that can be expressed as equation (1) shown below: (Kadirvelu $\mathrm{K}$ and Namasivayam C, 2000).

(1) $\quad q_{e}=\frac{b q_{\max } C_{e}}{1+b C_{e}}$

In the above equation, $q_{e}$ is the metal uptake at equilibrium (mg/g of biomass), $q_{\text {max }}$ is the maximum Langmuir uptake $(\mathrm{mg} / \mathrm{g}), C_{e}$ is the final metal concentration at equilibrium $(\mathrm{mg} / \mathrm{L})$, and $b$ is the Langmuir affinity constant $(\mathrm{L} / \mathrm{mg}$ of the metal). The Langmuir affinity constant correlates to the affinity between the biomass and a certain metal, with higher value indicating greater affinity. These sorption parameters can be calculated from the isotherm using a linear representation of the Langmuir model $\left(C_{e} / q_{e}\right.$ vs $\left.C_{e}\right)$ as shown in equation (2) below:

(2) $\frac{C_{e}}{q_{e}}=\frac{C_{2}}{q_{\max }}+\frac{1}{b q_{\max }}$

The Langmuir isotherm is based on the following assumptions (Langmuir I, 1918).

a) Metal ions are chemically adsorbed at a fixed number of well-defined sites.

b) Each site can hold only one ion.

c) All sites are energetically equivalent and there is no interaction between the ions.

The linear plot of $C_{e} / q_{e}$ vs $C_{e}$ showed that the adsorption followed the Langmuir adsorption model (Figure 1). The correlation coefficient was 0.99. $q_{\max }$ and $b$ were calculated from the slope and intercept of the plot and were 76.9 $\mathrm{mg} / \mathrm{g}$ and $0.209 \mathrm{~L} / \mathrm{mg}$ respectively. 


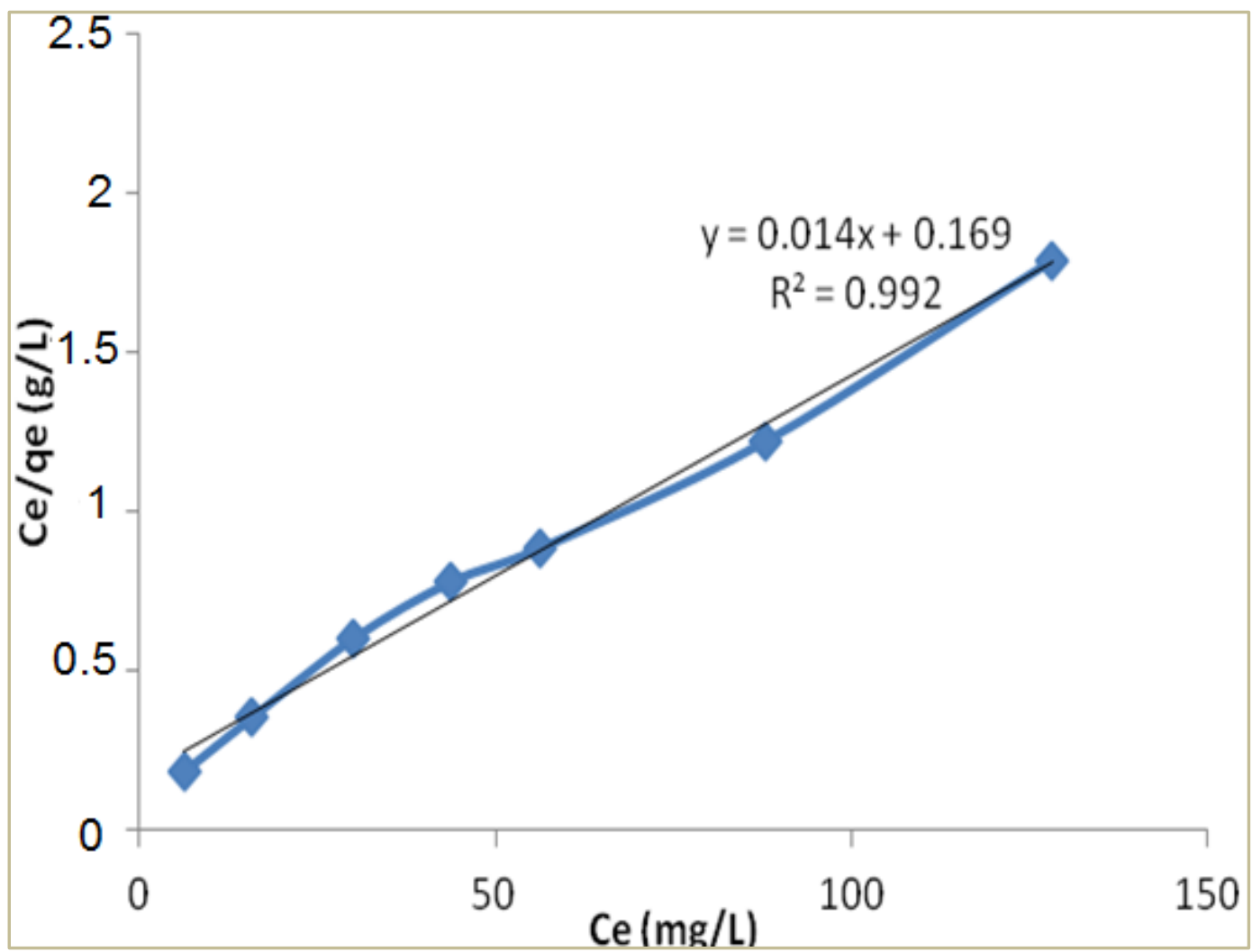

Fig.1:-Langmuir plot for $\mathrm{Cr}(\mathrm{VI})$ adsorption. Agitation time: $80 \mathrm{~min}$, initial $\mathrm{pH}$ : 2.0, initial adsorbate concentration: 40-200 mg/L, adsorbent dosage: $1 \mathrm{~g} / \mathrm{L}$, temperature: $30^{\circ} \mathrm{C}$.

\section{Separation factor $-\mathbf{R}_{\mathrm{L}}$ :-}

The necessary characteristics of the Langmuir isotherms wasexpressed in terms of a dimensionless constant separation factor or equilibrium parameter, $R_{L}$, which was defined as shown in equation (3) below where $C_{o}$ is initial concentration in $\mathrm{mg} / \mathrm{L}$ and $b$ is Langmuir constant:

(3)

$$
R_{L}=\frac{1}{1+b C_{o}}
$$

According to McKay $\mathrm{G}$ et al. (1982), $R_{L}$ values between 0 and 1 indicate favorable adsorption (Table 1).The $R_{L}$ values obtained in our study were less than 1 for $\mathrm{Cr}(\mathrm{VI})$ adsorption indicating favorable adsorption (Table 2).

Table 1:-Relation between separation factor $\left(R_{L}\right)$ and type of isotherm.

\begin{tabular}{|c|c|}
\hline$R_{L}$ value & Type of isotherm \\
\hline$R_{L}>1$ & Unfavorable \\
\hline$R_{L}=1$ & Linear \\
\hline$R_{L}<1$ & Favorable \\
\hline
\end{tabular}

Table 2:-Initial adsorbate concentration $\left(C_{o}\right)$ and resulting values of separation factor $\left(R_{L}\right)$

\begin{tabular}{|c|c|}
\hline $\boldsymbol{C}_{\boldsymbol{o}}$ & $\boldsymbol{R}_{\boldsymbol{L}}$ \\
\hline 40 & 0.116 \\
\hline 60 & 0.095 \\
\hline 80 & 0.073 \\
\hline 100 & 0.059 \\
\hline 120 & 0.049 \\
\hline 160 & 0.037 \\
\hline 200 & 0.030 \\
\hline
\end{tabular}


Freundlich adsorption was also applied in our study of adsorption of Chromium (VI) on to biosorbent. The Freundlich isotherm is represented by the equation (4) shown below (Freundlich H, 1906):

$$
q=K_{f} C_{e q}{ }^{1 / n}
$$

In the above equation, $C_{e q}$ is the equilibrium concentration $(\mathrm{mg} / \mathrm{L}), q$ is the amount adsorbed $(\mathrm{mg} / \mathrm{g}), K_{f}$ is the Freundlich constant, and $n$ is the heterogeneity factor representing the deviation from linearity of adsorption, also known as Freundlich coefficient. The linearised forms of Freundlich adsorption isotherm was used to evaluate the sorption data and was represented as equation (5) below:

$$
\ln q=\ln K_{f}+\frac{1}{n} \ln C_{e q}
$$

$K_{f}$ and $n$ were calculated from the slope of the Freundlich plots (Figure 2). A $n$ value between 1 and 10 represent beneficial adsorption and in our study, the value of $n$ wassignificant at 3.4.

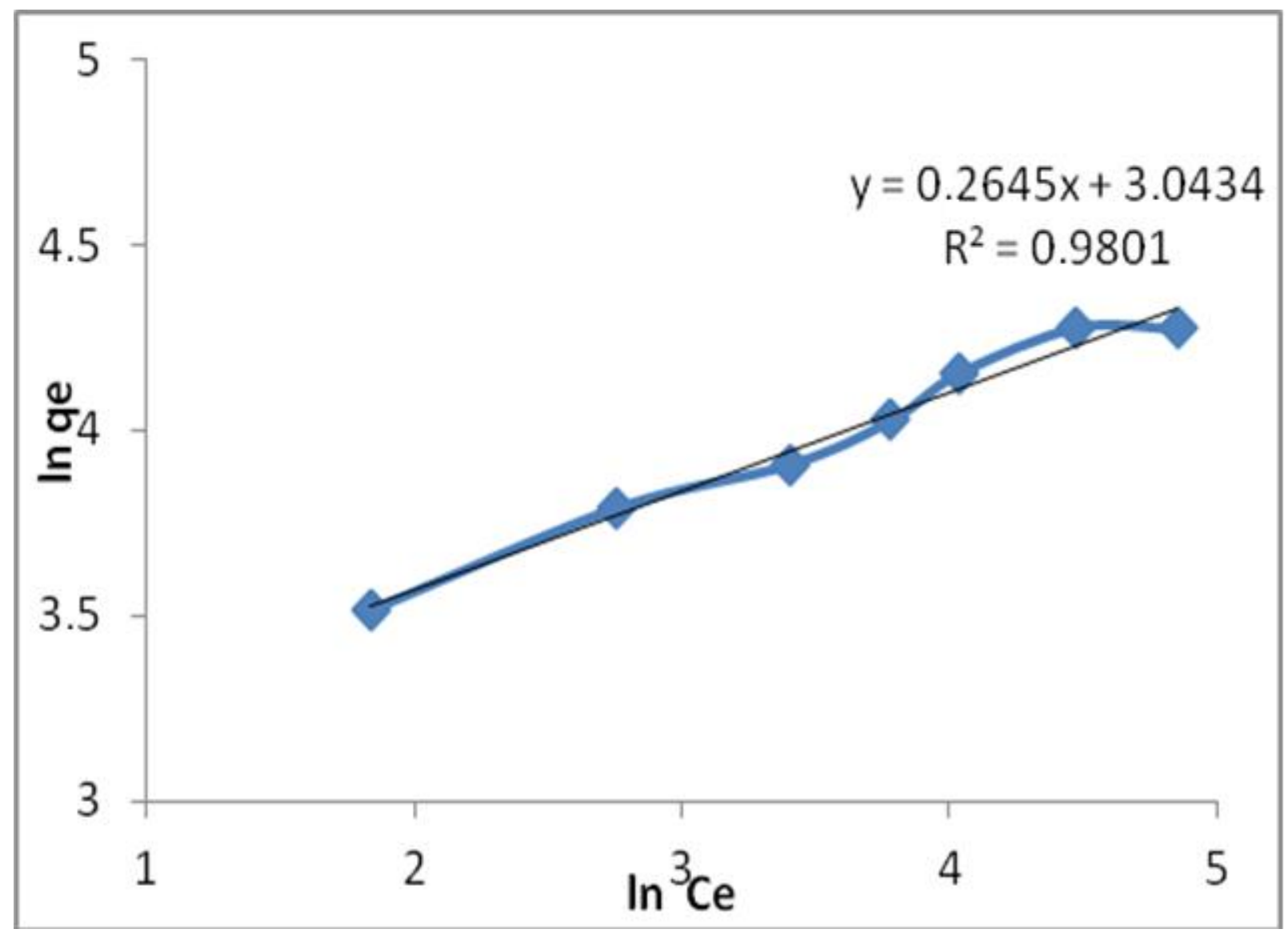

Fig. 2:-Freundlich plot for Cr (VI) adsorption. Agitation time: $80 \mathrm{~min}$, initial pH: 2.0, initial adsorbate concentration: $40-200 \mathrm{mg} / \mathrm{L}$, adsorbent dosage: $1 \mathrm{~g} / \mathrm{L}$, temperature: $30^{\circ} \mathrm{C}$.

\section{Effect of pH on adsorption:-}

To optimize the $\mathrm{pH}$ for maximum $\mathrm{Cr}(\mathrm{VI})$ removal which is an important factor, batch experiments were performed with $50 \mathrm{ml}$ of different concentration $(\mathrm{mg} / \mathrm{L})$ of metal ion solution by varying the $\mathrm{pH}$ between 2-6 and results were analysed. The metal chromium is known to exhibit $\mathrm{pH}$ dependent equilibria in aqueous solutions. As the $\mathrm{pH}$ shifts, the equilibrium also shifts. In the $\mathrm{pH}$ range of 2-6, $\mathrm{HCrO}_{4}{ }^{-}$and $\mathrm{Cr}_{2} \mathrm{O}_{7}{ }^{2-}$ ions are in equilibrium. But in the case of lower $\mathrm{pH}(\mathrm{pH}<2.0)$ values, $\mathrm{Cr}_{3} \mathrm{O}_{10}{ }^{-}$and $\mathrm{Cr}_{4} \mathrm{O}_{13}{ }^{2-}$ species are produced.

The optimum initial $\mathrm{pH}$ for biosorption of hexavalent chromium using our biosorbent was 2.0 in our study. The experimental results showed that the percentage adsorption increased as the $\mathrm{pH}$ was lowered and reached $99 \%$ and 97\% respectively for 20 and $40 \mathrm{mg} / \mathrm{L} \mathrm{Cr}$ (VI) concentrations (Figure 3). The decrease in percentage removal of chromium ion at higher $\mathrm{pH}$ is likely due to negative charges on surface of adsorbent repelling the ions. 


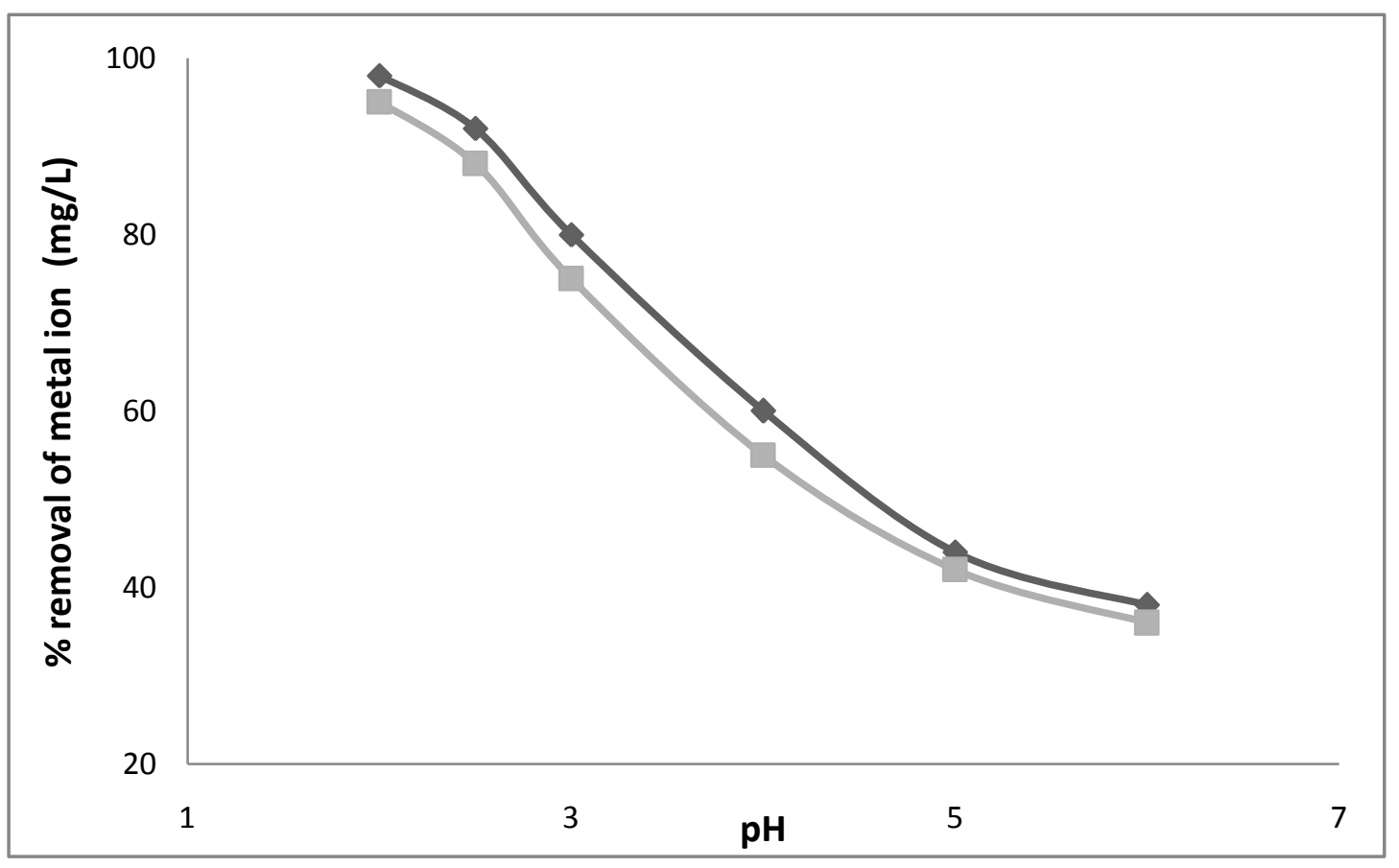

Fig. 3:-Effect of $\mathrm{pH}$ on $\mathrm{Cr}(\mathrm{VI})$ adsorption at different initial $\mathrm{Cr}(\mathrm{VI})$ concentrations. Initial concentration: $20 \mathrm{mg} / \mathrm{L}$ (black line), $40 \mathrm{mg} / \mathrm{L}$ (gray line).

Recently, information is available that Cr (VI) can be reduced to $\mathrm{Cr}$ (III) by contact with biomass due to high reduction potential values. This has been supported by X-ray photoelectron spectroscopy analysis (Park D et al., 2004). At the time of $\mathrm{Cr}$ (VI) reduction some of the organic carbons of the biomass are converted to inorganic carbon $\left(\mathrm{HCO}_{3}{ }^{-}\right.$and $\left.\mathrm{CO}_{2}\right)$. Thus in our study, with decreasing $\mathrm{pH}$, the protons were consumed during adsorption and more polymerized chromium oxide species were noted.

\section{Effect of agitation time and initial $\mathrm{Cr}$ (VI) concentration on $\mathrm{Cr}$ (VI) adsorption:-}

In our study, there were two stages of adsorption process noted. First stage was rapid where about $75 \%$ biosorption was completed within first 15-20 min and the second stage represented a slow progressive biosorption. The first stage was likely rapid due to accumulation of metals on the large available surface area of biosorbent. With the progressive decrease in available sites on biosorbent, adsorption process was slower during the second stage. Moreover, the initial deposited metal ions are known to penetrate the interior of the biosorbent through intra-particle diffusion which contributes to the slower process as well (Sangi MR et al., 2008).

We observed that the biosorption process attained equilibrium in 1 hour. The effect of agitation time for various initial concentrations was studied at $\mathrm{pH}$ 2. The percentage removal of $\mathrm{Cr}(\mathrm{VI})$ improved with an increase in agitation time and the equilibrium attained varied for different $\mathrm{Cr}(\mathrm{VI})$ concentrations. The time required to attain equilibrium for $40 \mathrm{mg} / \mathrm{L} \mathrm{Cr}(\mathrm{VI})$ initial concentration was 60 minutes and for $100 \mathrm{mg} / \mathrm{L} \mathrm{Cr}(\mathrm{VI})$ initial concentration was 80 minutes. The maximum percentage adsorption was $99 \%$ and $75 \%$ respectively (Figure 4 ). 


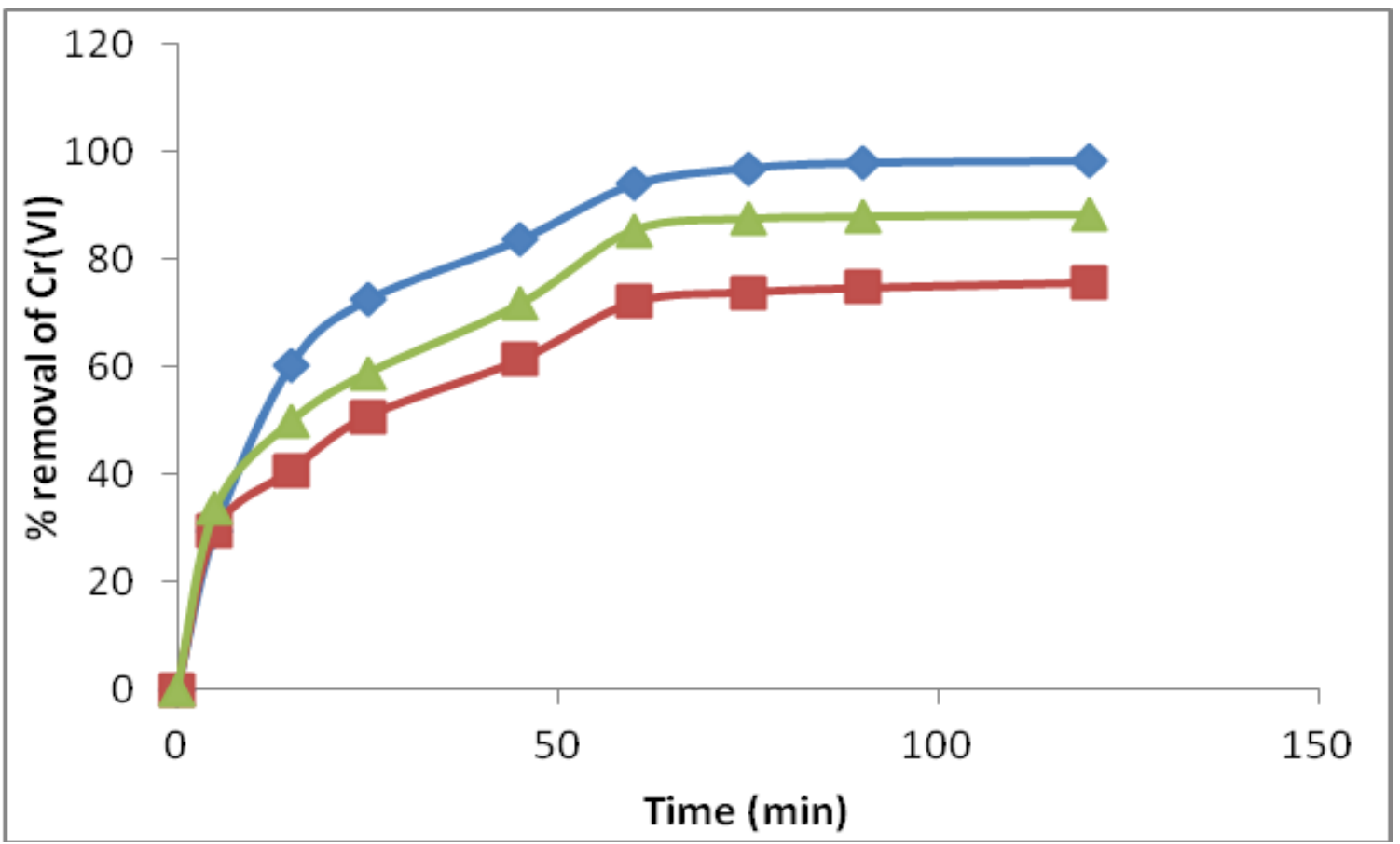

Fig. 4:-Effect of agitation time and initial Cr (VI) concentration. $\mathrm{pH} 2$, initial concentrations: $40 \mathrm{mg} / \mathrm{L}(\diamond), 80 \mathrm{mg} / \mathrm{L}$ $(\Delta)$, and $100 \mathrm{mg} / \mathrm{L}(\square)$.

\section{Effect of adsorbent dose on adsorption:-}

The percentage absorption of chromium (VI) was studied in relation to increasing adsorbent dose from 0.5 to $5 \mathrm{~g}$ added to $50 \mathrm{ml}$ aqueous solution with absorbate concentration of $100 \mathrm{mg} / \mathrm{L}$. We noted increased percentage removal from $65 \%$ to $99 \%$ as the dosage increased from 1 to $5 \mathrm{~g}$ but the adsorption capacity decreased (Figure 5).

The increase in percentage removal with increase in adsorbent dosage is due to increased availability of number of adsorption sites. However, the decrease in adsorption capacity can be explained by the fact that more sites remain unsaturated with increase in adsorbent dosage (Sharma DC and Forster CF,1993).

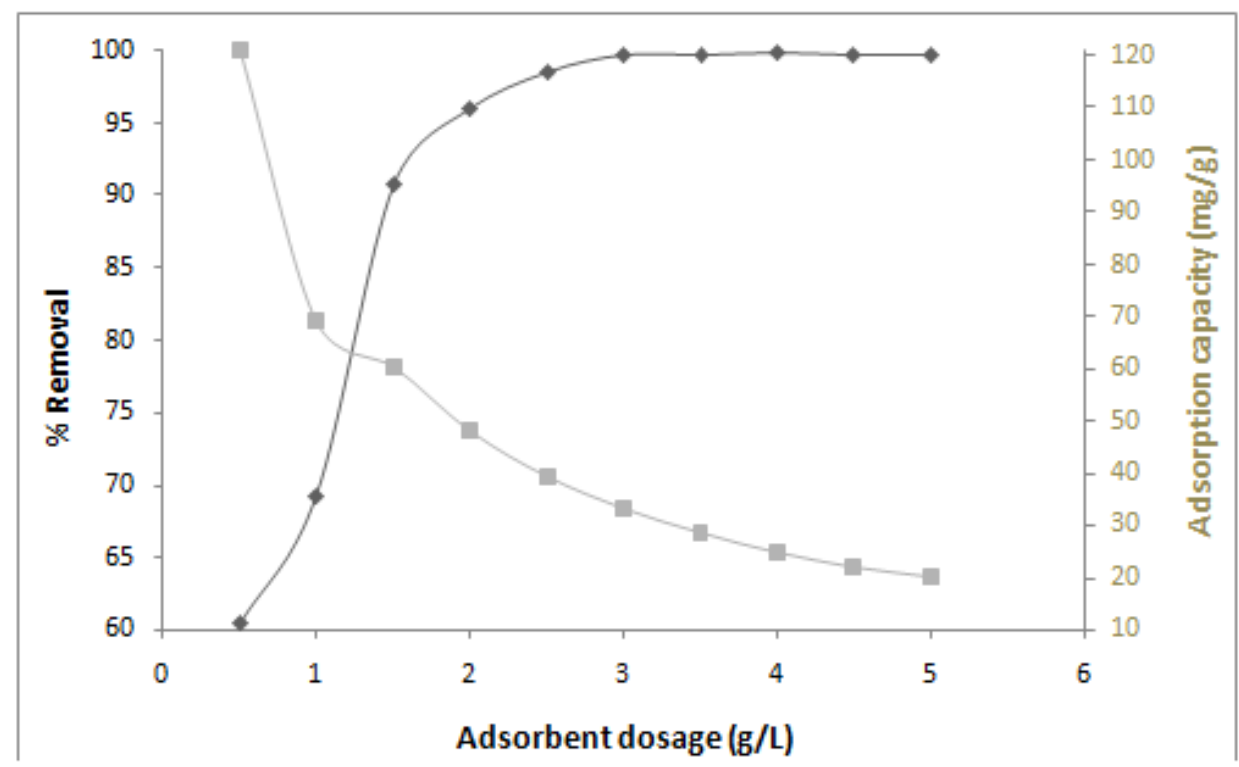

Fig. 5:-Effect of adsorbent dose on $\mathrm{Cr}(\mathrm{VI})$ adsorption. Time: $60 \mathrm{~min}$, temperature: $30^{\circ} \mathrm{C}$. 


\section{FTIR spectral analysis:-}

For further analysis, unreacted, chromium treated husk pellets were prepared and scanned using FTIR and percentage transmission for various wave numbers were studied. We identified absorption bands using obtained spectra and assigned them to corresponding functional groups (Figure 6).

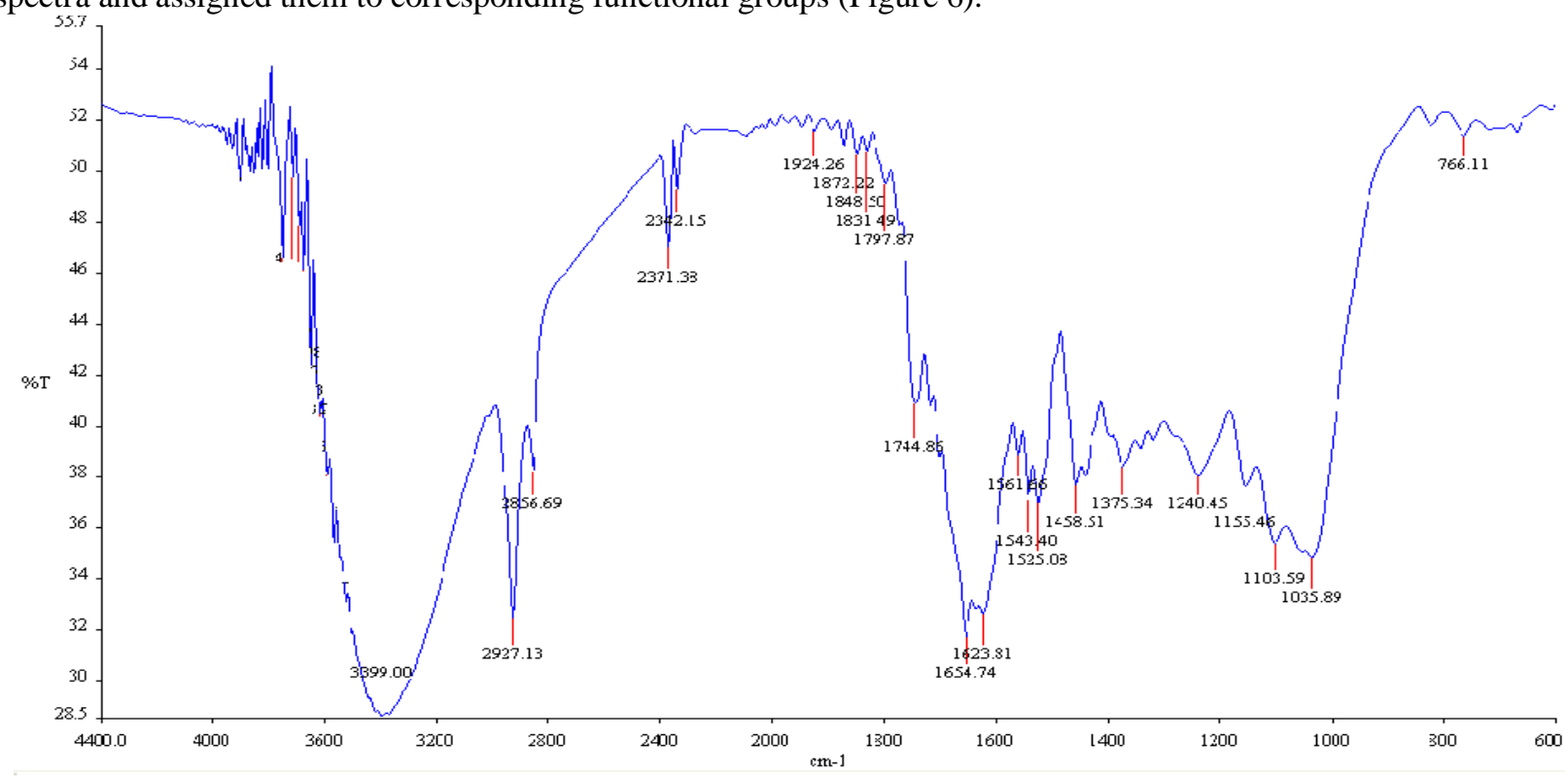

Fig. 6.Fourier transform infrared spectroscopy(FTIR) spectral analysis

Wave numbers of 3000 and $3750 \mathrm{~cm}^{-1}$ indicated presence of $\mathrm{OH}$ groups on the bisorbent surface. The trough that was observed at $2926 \mathrm{~cm}^{-1}$ and $893 \mathrm{~cm}^{-1}$ indicated presence of C-H groups. The $1649 \mathrm{~cm}^{-1}$ band was a result of CO stretching mode conjugated to a NH deformation mode and was indicative of amide band. The trough at $1154 \mathrm{~cm}^{-1}$ was due to $\mathrm{CO}$ or $\mathrm{CN}$ groups. Out data reflected the presence of several functional groups for binding $\mathrm{Cr}$ (VI) ions on biosorbent surface.

\section{Conclusion:-}

Results from our study strongly support the ability of cashew husk as an excellent alternative for removal Cr (VI) from solutions. The FTIR bands related to $-\mathrm{OH}$ and $-\mathrm{COOH}$ groups indicate that linocellulosic moieties of biosorbent that hold these groups play an important role in biosorption. Hydrogen of these groups is competent of ion exchange with metal ions.

We found maximum adsorption of $\mathrm{Cr}(\mathrm{VI})$ was at $\mathrm{pH}$ of 2 . The percentage removal increased with increase in adsorbent dosage and the equilibrium experiments showed that equilibrium was attained within 70 minutes. Langmuir isotherm showed $\mathrm{Cr}$ (VI) on cashew husk with maximum capacity of $56.9 \mathrm{mg} / \mathrm{g}$. Our study, through multiple analyses, showed that cashew husk can serve as an effective biosorbent for $\mathrm{Cr}$ (VI).

Cashew husk contains less amount of nitrogen (protein) and is advantageous over protein rich algal and other biomass projected metal biosorbents because proteinaceous materials are more likely to putrefy. Cashew husk, which is available in large quantities at various places in India, can be processed easily and in a very inexpensive manner to get sufficient adsorbent readily. Cashew husk as a biosorbent can be used in large scale industries to remove chromium ions from effluents and can be an effective alternative compared to other costly biosorbents and process.

Financial Disclosure:-The author has no financial relationships relevant to this article to disclose.

Conflict of Interest:- The author has no conflicts of interest to disclose. 


\section{References:-}

1. Ahalya N, Kanamadi RD, Ramachandra TV. (2005). Biosorption of chromium (VI) from aqueous solutions by the husk of Bengal gram (Cicerarientinum). Electronic Journal of Biotechnology, 8: 258-264.

2. Ahalya N, Kanamadi RD, Ramachandra TV. (2010). Removal of hexavalent chromium using coffee husk. International Journal of Environment and Pollution, 43: 106-116.

3. Aksu Z, Ozer D, Ekiz H, Kutsal T, Calar A. (1996). Investigation of biosorption of chromium (VI) on C. crispate in two-staged batch reactor. Environmental Technology, 17: 215-220.

4. Dakiky M, Khami A, Manassra A, Mer'eb M. (2002). Selective adsorption of chromium (VI) in industrial wastewater using low cost abundantly available adsorbents. Advances in Environmental Research, 6: 533-540.

5. Freundlich H. (1906). Ueber die Adsorption in Loesungen. Zeitschrift fur PhysikalischeChemie (Leipzig). 57: 385-470.

6. Hamadi NK, Chen XD, Farid MM, Lu MGQ. (2001). Adsorption kinetics for the removal of chromium (VI) from aqueous solution by adsorbents derived from used tyres and sawdust. Chemical Engineering Journal, 84: 95-105.

7. International Agency for Research on Cancer (IARC). (1982). Monographs on the evaluation of the carcinogenic risk of chemicals to humans. IARC, Lyon, France, Supplement 4.

8. Juang RS, Shiau RC. (2000). Metal removal from aqueous solution using chitosan - enhanced membrane filtration. Journal of Membrane Science, 165: 159-167.

9. Kadirvelu K, Namasivayam C. (2000). Agricultural by-products as metal adsorbents: sorption of lead (II) from aqueous solutions onto coir-pith carbon. Environmental Technology, 21: 1091-1097.

10. Kratochvil D, Volesky B. (1998). Advances in biosorption of heavy metals. Trends in Biotechnology, 16: 291300.

11. Langmuir I. (1918). The adsorption of gases on plane surfaces of glass, mica and platinum. Journal of the American Chemical Society, 40: 1361-1403.

12. Marshall WE, Champagne ET. (1995). Agricultural byproducts as adsorbents for metal ions in laboratory prepared solutions and in manufacturing wastewater. Journal of Environmental Science and Health - Part A Environmental Science and Engineering, 30: 241-261.

13. Mckay G, Blair HS, Gardener JR. (1982). Adsorption of dyes on chitin. I. Equilibrium studies. Journal of Applied Polymer Science, 27: 3043-3057.

14. OrhanY, Büyükgüngor H. (1993). The removal of heavy metals by using agricultural wastes. Water Science Technology, 28: 247-255.

15. Park D, Yun YS, Park JM. (2004), Reduction of hexavalent chromium with the brown seaweed Ecklonia biomass. Environmental Science and Technology, 38: 4860-4864.

16. Sangi MR, Shahmoradi A, Zolgharnein J, Azimi GH, Ghorbandoost M. (2008). Removal and recovery of heavy metals from aqueous solution using Ulmuscarpinifolia and Fraxinus excelsior tree leaves. Journal of Hazardous Materials, 155: 513-522.

17. Selvaraj K, Chandramohan V, and Pattabhi S. (1997). Removal of Cr (VI) from solution and chromium plating industry wastewater using photofilm waste sludge. Indian Journal of Chemical Technology, 18: 641-646.

18. Selvaraj K, Manonmani S, Pattabhi S. (2003). Removal of hexavalent chromium using distillery sludge, Bioresource Technology, 89: 207-211.

19. Sharma DC, Forster CF. (1993). Removal of hexavalent chromium using sphagnum moss peat. Water Research, 27: 1201-1208.

20. Srinivasan K, Balasubramanian N, Ramakrishna TV. (1988). Studies on chromium removal by rice husk carbon.Indian Journal of Environmental Health, 30: 376-387.

21. Volesky B, Holan ZR. (1995). Biosorption of heavy metals. Biotechnology Progress, 11(3): 235-250.

22. Volesky B. (1990). Biosorption of heavy metals. CRC Press, Boca Ratón, Florida, 396. 